\title{
Distance learning in higher education: current trends
}

\author{
Yaroshenko T.* \\ National University of Kyiv-Mohyla Academy, Kyiv, Ukraine
}

Received: $15.08 .2019 \quad$ Accepted: 21.12 .2019

\begin{abstract}
The article is dedicated to the current issues of using distance-learning technologies in higher education in Ukraine and the world. The major stages and reasons for the rapid growth in the world of universities providing distance learning under the influence of rapid development of information and communication technologies and the promotion of educational innovations, including MOOC (Massive Open Online Courses) and other, are discussed in detail such as electronic learning process management systems. The author examines and analyzes the main four steps that preceded and facilitated the emergence of distance learning, namely: communication through postal communications, communication via radio and television, communication via computer and media, communication through mass-based online courses. The article also looks at the current state and prospects of further development of distance education in Ukraine. The author points out, among other things, the basic normative provisions that determine the basic principles of creation, organization, and implementation of modern distance learning in Ukraine. In an article the basic principles of distance learning are formulated, the organizational and methodological conditions and the principles of its introduction into the educational process are substantiated; its main advantages and disadvantages are highlighted. This article specifically describes the importance of distance education for the implementation and implementation of the concept of Lifelong Learning. An important project of introducing distance (blended) learning at the National University of Kyiv-Mohyla Academy, in particular, the DistEdu platform. The article discusses the ways of engaging lecturers and students to work with this educational online platform. The article identifies directions for further development of distance education in Ukraine and outlines the potential of DistEdu-like projects in promoting distance education in the Ukrainian educational environment and the educational community.

Key words: distance learning, distance education, blended learning, educational process, massive online open courses, higher education.
\end{abstract}

\section{Дистанційне навчання в системі вищої освіти: сучасні тенденції Ярошенко Т. 0. \\ Національний університет «Києво-Могилянська академія», Київ, Україна}

\begin{abstract}
Анотація. Статтю присвячено актуальним питанням використання дистанційних технологій навчання в системі вищої освіти в Україні та світі. Докладно проаналізовано причини стрімкого зростання у світі кількості університетів, які здійснюють навчання студентів за дистанційною формою, внаслідок бурхливого розвитку інформаційно-комунікаційних технологій та популяризації освітніх інновацій, зокрема МВОК (масових відкритих онлайн-курсів, англ. MOOC - Massive Open Online Courses), а також інших електронних систем управління навчальним процесом. Авторка розглянула чотири основні етапи, що передували та сприяли появі дистанційного навчання, а саме: комунікація за посередництвом поштового сполучення, комунікація через радіо та телебачення, спілкування за допомогою комп'ютерної техніки та засобів, спілкування через масові онлайн-курси. Також розглянуто сучасний стан і перспективи подальшого розвитку дистанційної освіти в Україні. 3-поміж іншого вказано основні нормативні положення, які визначають базові засади створення, організації та запровадження сучасного дистанційного навчання в Україні. У цій статті сформульовано основні принципи дистанційного навчання, обґрунтовано організаційні та методологічні умови й засади його впровадження в навчальний процес, висвітлено його основні переваги та недоліки. Авторка, зокрема, наголошує на важливості дистанційної освіти для втілення та реалізації концепції навчання протягом життя (Lifelong learning). У статті висвітлено важливий проект впровадження дистанційного (змішаного) навчання в Національному університеті «Києво-Могилянська академія» (зокрема платфоорми DistEdu) та способи залучення викладачів і студентів до роботи з цією навчальною онлайн-платформою. Визначено напрями
\end{abstract}

Corresponding Author: Yaroshenko Tetiana Oleksandrivna. Tel. 044 425-60-55. E-mail: yaroshenko@ukma.edu.ua The National University of Kyiv-Mohyla Academy, vul. H. Skovorody, 2, Kyiv, Ukraine, 04070.

Відповідальний автор: Ярошенко Тетяна Олександрівна. Тел. 044 425-60-55. E-mail: yaroshenko@ukma.edu.ua Національний університет «Києво-Могилянська академія», вул. Г. Сковороди, 2, м. Київ, Україна, 04070. 
подальшого розвитку дистанційної освіти в Україні та потенціал подібних проектів для її популяризації в українському освітньому середовищі та освітній спільноті.

Ключові слова: дистанційне навчання, дистанційна освіта, змішане навчання, навчальний процес, масові онлайн-курси, вища освіта.

\title{
Дистанционное обучение в системе высшего образования: современные тенденции
}

\author{
Ярошенко Т. А. \\ Национальный университет «Киево-Могилянская академия», Киев, Украина
}

\begin{abstract}
Аннотация. Статья посвящена актуальным вопросам использования дистанционных технологий обучения в системе высшего образования в Украине и мире. Подробно проанализированы причины стремительного роста в мире количества университетов, осуществляющих обучение студентов по дистанционной форме, под влиянием бурного развития информационно-коммуникационных технологий и популяризации образовательных инноваций, в том числе МООК (массовых открытых онлайн-курсов, англ. MOOC - Massive Open Online Courses), a также других электронных систем управления учебным процессом. Автором рассмотрены четыре основных этапа, предшествовавших появлению дистанционного обучения, а именно: коммуникация посредством почтового сообщения, коммуникация через радио и телевидение, общение посредством компьютерной техники и средств, общение через массовые онлайн-курсы. Также рассматриваются современное состояние и перспективы дальнейшего развития дистанционного образования в Украине. Автором среди прочего указаны основные нормативные положения, определяющие базовые принципы создания, организации и внедрения современного дистанционного обучения в Украине. В данной статье ссрормулированы основные принципы дистанционного обучения, обоснованы организационные и методологические условия и принципы его внедрения в учебный процесс, освещены его основные преимущества и недостатки. Автором, в частности, подчеркнута важность дистанционного образования для воплощения и реализации концепции обучения в течение жизни (Lifelong learning). В статье освещен важный проект внедрения дистанционного (смешанного) обучения в Национальном университете «КиевоМогилянская академия» (в частности платформы DistEdu) и способы привлечения преподавателей и студентов к работе с этой учебной онлайн-платформой. Определены направления дальнейшего развития дистанционного образования в Украине и потенциал подобных проектов для его популяризации в украинской образовательной среде и образовательном сообществе.

Ключевые слова: дистанционное обучение, дистанционное образование, смешанное обучение, учебный процесс, массовые онлайн-курсы, высшее образование.
\end{abstract}

\section{Bcmyn}

Всесвітньовідомий професор теоретичної фізики Мічіо Кайку сказав: «У наступні 50 років освіта стане індивідуальною справою кожного і здійснюватиметься без педагога, за принципом "тільки ти і комп'ютер". Університети збережуться, але це будуть переважно відкриті, віртуальні В30, навчання в яких ґрунтуватиметься на хмарних сервісах. Тих, хто відвідуватиме лекції в традиційних закладах освіти, вважатимуть невдахами, про яких говоритимуть: "Він не зміг сам сконструювати свою освіту"» (цит. за: [5]).

Традиційні методи навчання в університетах, як, власне, і моделі університетів, у XXI столітті зазнають глибоких трансформацій через бурхливе впровадження інформаційно-комунікаційних технологій (IKT) як ключового засобу інновацій в освіті та навчанні (E \& T), а також з огляду на виклики часу щодо динамічного та гнучкого навчання протягом усього життя, а не в замкненій традиційній часопросторовій університетській системі. Ще один виклик сьогодення - широке впровадження масових онлайн-курсів і відкритих е-платформ, які конкурують із традиційними університетами [29].

Дистанційну освіту для навчання своїх працівників уже використовують 41,7 \% світових компаній зі списку Fortune 500, близько $50 \%$ університетів у світі так чи інакше залучають дистанційне (чи змішане) навчання для власних програм, а також створення масових онлайн-курсів [29].

Навчання завжди було важливим для розвитку особистості протягом усього життя, а сьогодні це необхідність, бо ж знання дуже швидко застарівають. Люди також цінують можливість швидкого доступу до знань та інформації в будь-який час та в будь-якому місці, незалежно від географії чи віку, матеріального стану чи стану здоров'я, зайнятості на роботі або ж інших чинників. 
Тенденція глобалізації також впливає на підвищення мобільності й вимагає дедалі більшого застосування інформаційних комунікацій, вдосконалення технологій надання освітніх послуг, пошуку нових підходів до навчання. Дистанційна освіта розширює коло споживачів освітніх послуг із різних регіонів, відкриває можливості здобути освіту та реалізує систему безперервного навчання впродовж усього життя, створює додаткові робочі місця, індивідуалізує навчання за одночасного забезпечення його масовості.

Цифрове (дистанційне, онлайн) навчання дуже швидко змінює наше уявлення про освіту: так чи інакше, але освіта поступово перебирається з традиційних аудиторій та лабораторій університетів у віртуальний простір, що надає їй додаткову цінність та новий потужний інструментарій.

Успіх та стрімкий розвиток цифрової освіти змушують бачити в ній взагалі майбутнє освіти: розширення можливостей та конкурентоспроможності вітчизняного ринку освітніх послуг, доступності для всіх категорій населення та інтеграцію до світового інформаційного простору зі збереженням людського капіталу.

\section{II Матеріал і методи дослідження}

Дистанційне навчання поєднує традиційні методи здобуття знань, нові інформаційні та телекомунікаційні технології, а також принципи самоосвіти. Платформи для цифрового навчання та методи їхнього використання стають різноманітнішими. В університетах зростає популярність змішаного навчання, що поєднує кращі методики традиційної та онлайн-освіти. Розвиваються політики (концепції, програми, нормативна база) для впровадження цифрової освіти в різних країнах світу, зокрема на теренах Європейського Союзу та України (див., напр., [6; 27; 35]).

Для максимальної ефективності дистанційного навчання потрібно його правильно організувати за допомогою системи організаційних, технічних, програмних та методичних заходів. Саме це й буде основним предметом дослідження цієї статті, також буде розглянуто досвід впровадження дистанційної освіти в НаУКМА.

\section{III Результати}

\section{Передумови впровадження дистанційного навчання}

Перші приклади дистанційного навчання мали радше характер заочної освіти, коли студенти повністю чи частково здобували знання (вивчення літератури, виконання завдань тощо) на відстані [17]. Одним з перших запровадив «навчання за листуванням» Берлінський інститут вивчення іноземних мов (з 1856 р.) Згодом кількість таких навчальних закладів, де спілкування викладачів та студентів відбувається через поштове листування зростає, географрія розширюється (Європа, США, Канада, Австралія та ін.). У 1892 р. у переліку кореспондентських курсів Університету штату Вісконсин (США) уперше вжито термін distant education (дистанційне навчання), хоча все ще йдеться про заочне (віддалене) навчання через листування.

У XX столітті завдяки масовому поширенню поштового, телеграфрного та телефонного зв'язку, а згодом - радіо та телебачення обсяги дистанційного (на віддалі) навчання істотно зросли. Поряд із традиційним навчанням в університетах створюються структури дистанційного (заочного) навчання 3 логістикою його навчального процесу. Відбувається юридичне визнання цієї форми навчання через підтвердження здобувачами набутої кваліфікації та отримання офіційних документів про освіту. Серед відомих прикладів можна назвати заснований у 1939 р. Французький національний центр дистанційного навчання (CNED) (https://www.cned.fr/). Нині це найбільший центр франкомовної освіти з фріліями у 120 країнах, де навчаються понад 200 тис. осіб на рік, зокрема 35 тис. студентів, що здобувають вищу освіту.

1969 року у Лондоні було засновано Британський відкритий університет (http://www.open.ac.uk/). Його місія - надати можливість здобути освіту людям, охочим учитися в зручному для них місці і в зручний час. За 50-річну діяльність цього закладу тут навчалися понад 2 млн осіб зі 157 країн світу, а щороку університет має 174 тис. студентів включно з 24 тис. осіб з обмеженими можливостями, 1700 осіб, що перебувають у місцях позбавлення волі тощо. Найстаршому випускникові університету 93 роки, а наймолодшому - 13. Усі технічні інновації також були застосовані тут, зокрема, навчальні 
матеріали доступні на смартфонах, понад 73 млн завантажень навчального контенту з додатка iTunes U тощо.

Інші приклади: Національний університет дистанційного навчання в Іспанії, Балтійський університет із центром у Стокгольмі (об'єднує 10 країн Балтійського регіону), Відкритий університет у Канаді (14 тис. студентів), Шанхайський телевізійний університет у Китаї (500 тис. студентів), Університет Ферн (Хаген) у Німеччині (55 тис. студентів), Голландський відкритий університет (22 тис. студентів), Міжнародний університет бізнесу у США (33 тис. студентів).

Поява та масове поширення персональних комп'ютерів, «народження» Інтернет і особливо Веб, сприяли стрімкому поширенню дистанційного навчання. Справді, створено якісно нові умови зручного спілкування всіх учасників навчального процесу. Самостійне навчання перетворюється в дистанційнодіалогове: студенти можуть не лише отримати всю потрібну інформацію (в зручний спосіб, зручний час тощо), але й взаємодіяти з викладачем чи тьютором.

На початку XXI століття у світі було понад 1100 закладів дистанційного навчання. У деяких країнах Європи та Азії нині до 30 \% студентів здобувають освіту в таких закладах. Прогнозується, що їхня кількість збільшиться до 50 \%. Дистанційне навчання кардинальним чином впливає на розвиток навчальних закладів, що підтверджує закордонний досвід. Найвпливовіші та найпрестижніші університети світу пропонують цілісне дистанційне або ж змішане навчання на всіх рівнях освіти (бакалаврський, магістерський, здобувачів $\mathrm{PhD}$ ), серед відомих проектів, наприклад, МIT OpenCourseWare (MIT OCW) Массачусетського інституту технологій, або edX (спільно від МІT та Гарвардського університетів), Стенфорд онлайн та ін. Зявляються моделі віртуальних університетів (що існують лише в мережі): Florida Virtual School (FLVS) (перший віртуальний університет США, заснований 1997 р., щороку навчає понад 100 тис. студентів) або University of Phoenix (до 400 тис. студентів на рік) та ін.

У 2008 році вперше вжито термін MOOC (масовий он-лайн курс): Дейв Кормер ( Dave Cormier) для курсу, що пропонувався Університетом Манітоби ("Connectivism and Connective Knowledge"), на який крім 25 студентів університету, записалось ще... 2,300 слухачів з усього світу. Курс викладався через низку засобів та технологій (включно з Moodle, RSS-стрічкою, спілкуванням на блозі, Second Life тощо). In 2012, MIT and Harvard spearheaded the edX initiative for the promotion of MOOCs.

Особливістю дистанційного навчання $є$ його доступність на освітніх ринках будь-яких країн. На початку 2019 р. у вільному доступі (безкоштовно або з частковою оплатою) було викладено вже понад 10 тис. масових онлайн-курсів від 800 провідних університетів світу [35], а такі освітні платформи, як Coursera, Udacity, Udemy, edX або ж українські Prometheus чи Відкритий університет Майдану, збирають сотні тисяч охочих до набуття знань чи вмінь з окремої дисципліни. Такі платформи, звісно, теж співпрацюють з університетами. Наприклад, Coursera встановила співпрацю з різними університетами по всьому світу, щоб викладати курси цих закладів онлайн. Нині на платформі пропонуються різноманітні курси з багатьох спеціальностей та галузей для зареєстрованих слухачів. Кількість слухачів перевищила $10 \mathrm{mлн} \mathrm{осіб!} \mathrm{Усі} \mathrm{курси} \mathrm{доступні} \mathrm{на} \mathrm{безкоштовній} \mathrm{основі,} \mathrm{але} \mathrm{для} \mathrm{отримання} \mathrm{сертифіката}$ треба внести оплату або подати заявку на фінансову підтримку. Вартість сертифіката в середньому становить 30-40 доларів. Тривалість курсу - від 3 до 6 тижнів, протягом яких слухачі в зручний для них час можуть переглядати лекції та виконувати завдання інструкторів курсу.

Найпопулярніші платформи дистанційного навчання з усього світу:

Coursera - https://www.coursera.org/

Khan Academy - https:/luk.khanacademy.org/

Udacity - https://www.udacity.com/

Stanford Open Edx - http://online.stanford.edu/

Codecademy - https://www.codecademy.com/

Prometeus - https://prometheus.org.ua/.

EdEra - https://www.ed-era.com/

$E d X-$ https://www.edx.org/

Future Learn - https://www.futurelearn.com/

Canvas Network - https://www.canvas.net/

OpenupEd - http://openuped.eu/ 
Iversity - https://iversity.org/ та ін.

Отже, можна виділити чотири основні етапи, що передували появі та сприяли розвитку дистанційного навчання.

Перший етап: з середини XIX ст. - фактично заочне навчання, коли комунікація між викладачами і студентами відбувалася шляхом поштового листування. Отримання завдань та відправлення виконаних робіт потребували значного часу, тож така система була малоефективною і значно поступалася очній системі навчання.

Другий етап - з початку XX ст., пов'язаний з появою спочатку радіо, а потім - телебачення, що забезпечило оперативніші та гнучкіші канали комунікації між студентами та викладачами. В багатьох університетах світу навіть зявляються власні телестудії, лекції транслюються на власних каналах та (чи) розсилаються на CD-ROMs.

Третій етап розпочався приблизно з 1991 р., відколи Тім Бернерс-Лі з фізичної лабораторії CERN продемонстрував роботу першого веб-браузера. За кілька років Веб стає одним з найпопулярніших інформаційних середовищ, зокрема і для оперативного зв'язку між викладачем і тим, хто навчається, а також доступу до значного обсягу навчальних курсів та матеріалів в мережі.

Четвертий етап - триває приблизно з 2008 р.: створення моделі та широке розповсюдження масових онлайн-курсів (МООС), в т.ч. університетського рівня, що спричинило взагалі зміну парадигми освітнього процесу. Масові он-лайн курси - як правило безкоштовні веб-платформи для дистанційного навчання великої кількості студентів, які географрічно розселені в різних місцях. Пропонуються університетами чи коледжами або можуть бути незалежними (поєднувати курси різних викладачів чи тренерів від різних університетів та кампаній). Хоча МOOC не завжди пропонують академічні кредити, але надають освіту, яка може забезпечити сертифікацію, працевлаштування або продовження навчання. Відтак вчитися можна в зручний час з будь-якого місця на земній кулі, у кращих науковців та фахівців світового рівня, за зручним графіком, рідною мовою (наприклад, понад $60 \%$ студентів Coursera проживають не у США, курси запропоновані різними мовами, в т.ч. й українською). Переваг додає спілкування на форумах чи в соціальних мережах; сертифікатом Coursera можна скористатися під час співбесіди чи для зарахування заліку в університеті (кількість університетів, що зараховують кредити за сертифікатами Coursera, постійно збільшується). Хоча переважно англійська мова використовується в дистанційному навчанні в глобальному світі, все більше регіональних проектів пропонують курси національними мовами (див., наприклад, MéxicoX, FUN (France Université Numérique), проект NPTEL (National Programme on Technology Enhanced Learning, Індія), в Україні - Prometheus, Відкритий університет Майдану та ін.

Серед недоліків, які часто згадують: недосконала система оцінювання студентів; можливий плагіат. «Студентська аудиторія» на масових курсах часто сягає кілька тисяч, а це унеможливлює належну комунікацію з викладачем. Форуми часто неструктуровані.

\section{Впровадження дистанційного навчання в Україні}

В Україні розвиток дистанційного навчання почав прискорюватись з моменту ухвалення Закону України «Про Національну програму інформатизації» [21], а також Постанови Кабінету Міністрів України від 23.09.2003 р. № 1494 «Про затвердження Програми розвитку системи дистанційного навчання на 2004-2006 роки» [20]. 23 червня 2005 р. Колегія МОН України ухвалила рішення «Про стан і перспективи розвитку дистанційного навчання в Україні» [22], а 25 квітня 2013 р. Міністерство освіти і науки України видало Наказ № 466 «Про затвердження Положення про дистанційне навчання», в якому визначено поняття дистанційного навчання [19].

Розроблено проекти Ліцензійних умов надання освітніх послуг у сфрері вищої освіти за дистанційною формою навчання та Норм часу для планування і обліку навчальної роботи педагогічних та науково-педагогічних працівників вищих навчальних закладів, які забезпечують навчання за дистанційною формою, розроблено Положення про регіональні центри тощо. Ці документи визначають політику держави в галузі інформатизації та регулюють дистанційне навчання.

Дистанційне навчання може здійснюватися на всіх рівнях освітньої системи, хоча найбільш доцільним і прийнятним воно є у вищій школі, а також як метод самоосвіти. Піонерами у запровадженні елементів дистанційного навчання серед ЗВО України стали Національний технічний університет України «Київський політехнічний інститут», Хмельницький національний університет, Одеська 
національна академія харчових технологій, Сумський державний університет та ін. (перелік https://mon.gov.ua/ua/osvita/visha-osvita/distancijna-osvita/navchalni-zakladi-yaki-nadayut-mozhlivistnavchatis-viddaleno)

Сутність дистанційного навчання, основні способи його організації у вищій школі, особливості, переваги, недоліки

Дистанційне навчання є особливою педагогічною технологією, що базується на принципах відкритого навчання з використанням інформаційно-комунікаційних технологій (ІКТ), які забезпечують взаємодію між усіма учасниками процесу навчання. «Під дистанційним навчанням розуміється індивідуалізований процес набуття знань, умінь, навичок і способів пізнавальної діяльності людини, який відбувається в основному за опосередкованої взаємодії віддалених один від одного учасників навчального процесу у спеціалізованому середовищі, яке функціонує на базі сучасних психологопедагогічних та інформаційно-комунікаційних технологій» [19].

Вітчизняні науковці під дистанційним навчанням також розуміють таку форму навчання, яка використовує глобальні комп'ютерні комунікації (Інтернет) і базується на індивідуальній роботі осіб, що навчаються, з чітко підібраним навчальним матеріалом та активним спілкуванням із викладачами й іншими учасниками.

Різноманітні підходи до розуміння дистанційного навчання (ДН) спричинили появу великої кількості визначень цього поняття. Наведемо лише деякі з них, які здаються, на нашу думку, найбільш точними:

ДН є послідовним інтерактивним асинхронним процесом комунікації суб'єктів і об'єктів навчання між собою та із залученням засобів навчання.

ДН - нова організація освітнього процесу, основою якої $є$ принцип самостійного навчання студента, коли студенти в більшості віддалені від викладача в просторі й часі, проте мають можливість у будь-який момент підтримувати діалог за допомогою засобів телекомунікації.

ДН - сукупність інформаційних технологій, що забезпечують основний обсяг навчального матеріалу; інтерактивну взаємодію студентів з викладачами в процесі навчання; надання можливості самостійної роботи, а також оцінювання знань та вмінь у процесі навчання.

ДН - форма освіти (поряд 3 очною та заочною) 3 використанням кращих традиційних та інноваційних засобів і форм навчання, основою якого $є$ цілеспрямована та контрольована самостійна робота студента, не прив'язана до конкретного місця чи часу, з використанням спеціальних засобів навчання й погодженою можливістю контакту з викладачем.

ДН - форма навчання, що базується на виборі широкого спектра традиційних і нових інформаційних та телекомунікаційних технологій та технічних засобів, які створюють умови для діалогового обміну з викладачем.

Інформаційно-освітнє середовище ДН становить системну сукупність із засобів передачі даних, інформаційних ресурсів, протоколів взаємодії, апаратно-програмного та організаційно-методичного забезпечення і орієнтується на задоволення освітніх потреб користувачів.

ДН забезпечує неперервну освіту, що покликана реалізувати права людини на освіту і отримання інформації.

Дистанційна освіта досконало поєднує елементи очного, очно-заочного, заочного й вечірнього навчання на основі IKT та систем мультимедіа.

Дистанційна освіта - комплекс освітніх послуг, що базується на засобах обміну навчальною інформацією на відстані.

Така велика кількість визначень поняття «дистанційне навчання» та його похідних («дистанційна освіта», «віртуальна освіта» тощо) $є$ свідченням стрімкого розвитку цієї галузі освітньої діяльності та намагання знайти найбільш оптимальне її науково-методичне і технологічне наповнення.

Основними принципами системи дистанційної освіти $€$ відкритість, гнучкість, динамічність, модульність, адаптивність, неперервність, креативність. Як ми розуміємо, дистанційна освіта базується переважно на самостійному отриманні студентом необхідного обсягу і якості знань та передбачає поєднання широкого спектра традиційних і новітніх інформаційних технологій. Використання цих технологій дає змогу розвинути уміння та навички, які і в подальшому визначатимуть успішність людини: вміння самостійно планувати свою діяльність; приймати рішення, робити вибір і відповідати за 
нього; відбирати потрібну інформацію, структурувати і використовувати їі. Такі навички потрібні сьогодні кожному з огляду на потреби постійного «навчання впродовж життя».

І все ж розглянемо досвід впровадження дистанційного навчання у вищій школі. Університети України, як правило, все ще використовують «змішане навчання» як поєднання традиційного та дистанційного. Таке навчання дозволяє врахувати індивідуальні освітні потреби кожного, забезпечити критерії вимогливості та контролю тощо, але й надає можливості більш гнучкого фрормування та виконання навчальних програм та взаємного спілкування учасників освітнього процесу, одночасне використання джерел навчальної інформації багатьма студентами, зниження питомих витрат на навчання порівняно з традиційною системою освіти тощо.

Потрібно назвати і певні недоліки дистанційного навчання у вищій школі, зокрема:

-викладачам треба набагато більше часу і зусиль для створення навчального контенту, який би відповідав вимогам дистанційного навчання. У зв'язку 3 цим багато викладачів не бажають використовувати електронне навчання без додаткової мотивації;

-для успішного виконання основних завдань дистанційної освіти потрібно підвищити кваліфрікацію викладачів щодо застосування на практиці дистанційних методів навчання, використання комп'ютерної техніки та програмних засобів для їх реалізації;

-студенти мають отримати чіткі роз'яснення щодо мети впровадження таких форм навчання, результатів, які від них очікуються, а також на достатньому рівні оволодіти технологіями і програмним забезпеченням.

Незважаючи на зазначені проблеми і недоліки, можна стверджувати, що запровадження нової, дистанційної форми навчання підвищує ступінь відкритості навчального середовища і забезпечує можливість здобуття освіти альтернативними способами в тих випадках, коли ті, хто навчається, не використовують традиційного навчання.

Залежно від типу взаємодії між учасниками навчального процесу, засобів навчання, способів надання навчальних матеріалів виокремлюють різні моделі, за якими може здійснюватися дистанційне навчання [24].

Вирізняють декілька способів організації дистанційної освіти у ЗВО.

Перший - вся діяльність навчальних закладів здійснюється в середовищі глобальної мережі. Такі ЗВО іноді називають «віртуальними університетами», весь освітній процес (вибір напряму підготовки, проведення занять, виконання контрольних і тестових завдань та їх перевірка, поточний і підсумковий контроль, оплата за освітні послуги) здійснюється через Інтернет. Наразі кількість таких навчальних закладів незначна, зокрема, внаслідок недостатнього поширення швидкісних каналів зв'язку, особливо у сільських районах; високих вимог до рівня кваліффікації технічного персоналу та педагогічного колективу такого віртуального навчального закладу; нерозвиненості нормативно-правових механізмів підтримки такої форми освітньої діяльності.

Другий - більш поширеними сьогодні $є$ навчальні заклади, у яких реалізується технологія змішаного (або гібридного) навчання, яка передбачає поєднання традиційного (очного) та дистанційного (30-70\%) навчання. Вважається, що така форма навчання дає змогу поєднати переваги традиційних аудиторних занять із гнучкістю та зручністю дистанційної освіти. Науковці вирізняють й інші форми змішаного навчання, зокрема змішування структурованого та неструктурованого навчання; користувацького контенту і зовнішніх матеріалів; самостійного і колективного навчання; роботи і навчання тощо. Виділяють чотири основні організаційні моделі здійснення змішаного навчання: ротаційну, гнучку, модель самостійного навчання, модель збагаченого віртуального навчання.

Ротаційна модель передбачає зміну форматів навчання, серед яких принаймні одним із форматів $\epsilon$ дистанційне (онлайн) навчання. Решта форматів може передбачати роботу в малих групах, індивідуальні консультації викладача, групові проекти, письмові роботи тощо.

За гнучкої моделі кожен студент має гнучкий індивідуальний план навчання, проходження якого відбувається за підтримки викладача. Студенти здебільшого навчаються в аудиторіях та виконують індивідуальні домашні завдання. За потреби підтримка викладача може надаватися через роботу в невеликих групах, групові проекти, індивідуальні чи групові консультації.

Модель самостійного навчання передбачає, що студенти вивчають певні дисципліни онлайн, під керівництвом викладача, який бере участь у цьому процесі лише дистанційно. Таке навчання може 
відбуватися як удома, так і в навчальному закладі (за умови наявності необхідного приміщення та обладнання). Вважається, що така модель має поєднуватись із аудиторним вивченням інших дисциплін.

Модель збагаченого віртуального навчання передбачає поєднання традиційного та дистанційного навчання в такий спосіб: спочатку студенти вивчають дисципліну у вигляді аудиторних занять, а потім завершують навчання дистанційно. Відповідно викладач працює і традиційно, і дистанційно, надаючи онлайн-консультації.

Незважаючи на значну зацікавленість освітніх закладів України та певні позитивні зрушення в розвитку дистанційної освіти, слід зазначити певні проблеми, які гальмують цей процес, зокрема:

- немає системного підходу до розвитку дистанційної освіти в країні на державному рівні, наслідком чого $є$ недостатня узгодженість дидактичного та методичного забезпечення дистанційного навчання для різних рівнів освіти;

- незадовільна система підготовки кадрів для діяльності в цій сфері;

- немає єдиних вимог до спеціального програмного і методичного забезпечення;

-немає стратегії комплексного розвитку національного освітньо-наукового інформаційного середовища України, яке б охоплювало розвиток каналів зв'язку, баз даних та знань, систем управління освітою і наукою, що знижує рентабельність систем дистанційного навчання, сповільнює інтеграцію до європейських освітньо-наукових комп'ютерних мереж та інфрормаційних ресурсів;

-відсутність з боку держави фінансування розвитку системи дистанційного навчання;

-недостатня сфрормованість та недосконалість нормативно-правового забезпечення дистанційної форми навчання.

\section{Програмні продукти для управління навчанням у системі дистанційного навчання}

Центральний елемент, навколо якого збираються учасники дистанційної освіти, - е-платформи. Саме в цьому середовищі викладач створює курс, наповнює (зокрема мультимедійними ресурсами) та індивідуалізує його до потреб та здібностей кожного студента, здійснює підтримку діяльності студентів. Студент має доступ до всього контенту курсу, організовує свою роботу, виконує практичні вправи чи завдання, бачить еволюцію своєї освітньої діяльності, виконує завдання для самооцінки чи взаємодіє 3 викладачем через перевірку завдань на оцінку. Викладачі та студенти спілкуються індивідуально або в групі, пропонують теми для обговорення, можуть створювати спільні документи тощо. Адміністратор забезпечує й підтримує обслуговування такої системи: управляє доступом та правами викладачів і студентів, створює зв'язки із зовнішніми інформаційними системами (адміністративними документами, каталогами, науковими ресурсами тощо).

Для створення, передання й збереження навчально-методичних матеріалів, організації й супроводу процесу дистанційного та змішаного навчання за допомогою телекомунікаційного зв'язку найчастіше використовують такі застосунки: Learning Management System (LMS), Student Information Systems (SIS), Learning Content Management Systems (LCMS), Virtual Classrooms (VC), Virtual Learning Environments (VLE), Assessment Management Systems (AMS), Training Management Systems (TMS), Social Learning Systems, eBooks Management Systems, Learning Analytics, Massive Open Online Courses (MOOCs) тощо.

Найпоширенішими є системи управління навчанням (англ. LMS - Learning Management System) комп'ютерний програмний комплекс, який використовується для розроблення, управління та поширення навчальних онлайн-матеріалів із забезпеченням спільного доступу до них. Такі комплекси прості в застосуванні, навіть якщо викладачі не мають глибоких знань програмування. Створюються такі матеріали у візуальному навчальному середовищі із зазначенням послідовності їх вивчення. До матеріалів входять індивідуальні завдання, проекти для роботи в малих групах, інші навчальні елементи для всіх студентів, що базуються на змістовій і комунікативній складовій.

Сьогодні платформи дистанційного навчання функціонують у двох варіантах: із закритим кодом (комерційні) та відкритим кодом (поширюються безкоштовно).

Очікується, що до 2021 р. ринок LMS становитиме майже 16 млрд доларів США [29].

Американська компанія «Blackboard Inc.» (www.blackboard.com), яка розробила однойменну платформу для електронного навчання, $€$ світовим лідером серед розробників комерційних продуктів. Компанія володіє цілою лінійкою програмних продуктів, які активно використовуються для організації навчального процесу на всіх рівнях освіти по всьому світу, а особливо в Північній Америці і Японії. 
Принагідно назвемо й інші комерційні топ-продукти (cloud-Based Learning Management Systems): Docebo, Adobe Captivate Prime, Litmos LMS, iSpring Learn, Talent LMS, GnosisConnect, 360Learning LMS, The Academy LMS, Kallidus Learn та ін. ).

Програмні продукти з відкритим кодом (безкоштовні) також $€$ різноманітними, серед найпопулярніших: Atutor (http://www.atutor.ca), Dokeos (http://www.dokeos.com), DotLRN (http://www.dotlrn.org), ILIAS (http://www.ilias.de/index.html), LON-CAPA (http://www.lon-capa.org), Moodle (http://moodle.org), OpenUSS (http://www.openuss.org), Sakai (http://sakaiproject.org), SpaghettiLearning (http://www.spaghettilearning.com).

В Україні найвідомішою є освітня онлайн-платформа Moodle (модульне об'єктно-орієнтоване динамічне навчальне середовище) - безкоштовна, відкрита (Open Source) система управління навчанням, що реалізуе філософрію «педагогіки соціального конструктивізму», орієнтована на організацію взаємодії між викладачем та студентами. Головним розробником системи є австралієць Мартін Дугімас. Наразі Moodle має численні багатомовні версії, зокрема й українську. Систему застосовують у 175 країнах світу.

Досвід впровадження дистанційного (змішаного) навчання в Національному університеті «Києво-Могилянська академія»

Відроджений після 185-річної вимушеної перерви, НаУКМА на сучасному освітньому ринку діє 3 1992 р., є нині авторитетним класичним університетом (22 бакалаврські, 27 магістерських, $15 \mathrm{PhD}$ програм), має потужний інтелектуальний потенціал викладацького складу, виконує спільні міжнародні наукові та освітні проекти тощо. Окремі елементи впровадження дистанційної освіти впроваджені в HаУKMA ще з кінця 1990-х років (MOODLE на фракультеті інформатики, електронні бібліотеки та інституційний репозитарій як ресурсна база, модуль Course Reserve в інформаційно-бібліотечній системі (ALEPH) тощо. Втім, це були окремі рішення, які не впливали на систему навчання в цілому. Більш активне впровадження програми інформатизації пов'язано із завданнями Стратегічного плану розвитку НаУКМА на 2015-2025 рр. та проектом «Цифровий університет», що виконується з 2015 року. Передбачено, зокрема, всебічну інфрорматизацію та створення на базі НаУКМА моделі сучасного університету, який органічно поєднує традиційне та дистанційне навчання на основі сучасних технологій та потужної електронної бібліотеки, розвиток електронної науки та е-колаборації, впровадження електронного врядування, е-документообігу, низки електронних сервісів тощо. Розроблено концепцію електронної освіти в НаУКМА та цільову «Програму створення і розвитку електронної (змішаної, blended) освіти в НаУКМА на 2018-2023 рр.», втілення якої відбувається. Розроблено Положення про дистанційне навчання, створено Координаційну раду з питань електронної (змішаної, blended) е-освіти. Розпочав роботу загальноуніверситетський Центр е-освіти. Проведено загальноуніверситетське дослідження «Цифрова компетентність: чи готові ми до впровадження е-освіти». Оновлено платформу для навчання (DistEdu@NaUKMA/ Moodle), придбано обладнання для класів дистанційного навчання (зокрема, для здобувачів PhD в межах проекту DocHub від Erasmus+ ("Structuring Cooperation in Doctoral Research, Transferrable Skills Training, and Academic Writing instruction in Ukraine's regions"). Розроблено систему мотивації викладачів до створення та наповнення курсів. Проводяться регулярні вимірювання ефективності впровадження Програми (зокрема, через опитування викладачів та студентів, програми професійного розвитку викладачів тощо). Окремі методичні рішення щодо впровадження віртуальної мобільності та змішаного навчання розроблені в межах проекту MILETUS (Erasmus+, KA2, розвиток потенціалу вищої освіти). За цей час кількість курсів, розміщених на еплатформі зросла з 30-40 у 2015 до 740 у 2019, відбувається їх наповнення, вдосконалення, розвиток. Найбільше таких курсів для першого року навчання на бакалаврських програмах (165) та магістерських програмах (121). Середня відвідуваність е-платформи за день - 2200 (тобто понад 55\% студентів щодня використовують ці можливості). Створені також масові он-лайн курси від НаУКМА (3НО 3 математики, 3НО з англійської, Історія КМА, Наукова комунікація та ін.), розміщені на платформі Prometheus. Регулярно проводяться тренінги для викладачів з методики створення курсів на еплатформі та організації ефективної комунікації зі студентами. Заплановано низку подальших заходів розвитку та впровадження змішаного та дистанційного навчання. Очікується, що до 2025 року всі курси університету (3500+) будуть розміщені на е-платформі, створено не менше 10 окремих сертифікатних 
віртуальних програм, та 30 масових онлайн курсів для різних цільових категорій та різної спрямованості (учні шкіл, переміщені особи та ветерани, люди третього віку та ін.).

Послідовність у впровадженні процесу в НаУКМА відповідає рекомендаціям та вже перевіреній часом практиці:

-розроблення концепції;

-створення підрозділу;

-технічне забезпечення та програмна платформа;

-створення дистанційних курсів, електронних навчальних ресурсів;

- мотивація викладачів до створення курсів та відповідне регулярне навчання;

-залучення студентів.

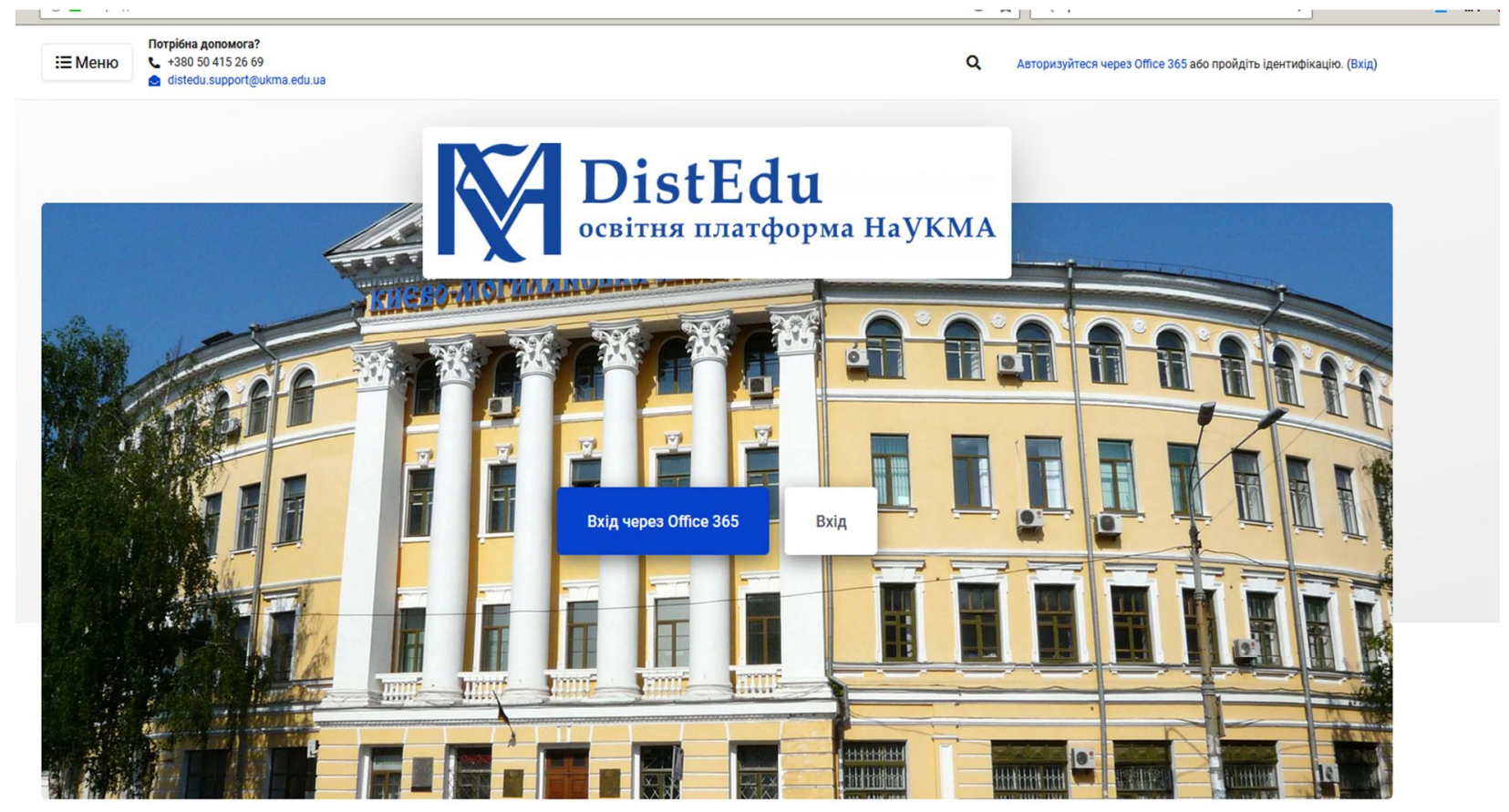

Пошук курсів

Вхід

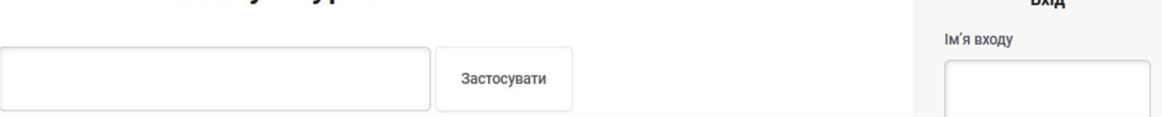

Рисунок. Скриншот платформи дистанційного навчання в НаУКМА (доступно понад 700 активних курсів)

\section{IV Обговорення}

Над обґрунтуванням фрілософських, психолого-педагогічних, методологічних засад розвитку дистанційного навчання працюють багато зарубіжних і вітчизняних науковців, зокрема: В. Бублик [3], В. Вишнівський [17], Г. Гайдур [17], М. Гніденко [17], М. Глибовець [23], І. Козубовська [10], В. Кухаренко [12], Н. Морзе, О. Овчарук, І. Ставицька [24], А. Піччіано [31; 32] та ін. Проте впровадження технологій дистанційного та змішаного навчання у системі вищої освіти, окремі педагогічні та психологічні аспекти проблематики все ще є предметом дискусій, експериментів, потребують додаткових студій.

Дистанційне навчання спонукає до впровадження інтерактивних технологій викладання матеріалу, має такі переваги, як гнучкість, актуальність, інтерактивність, мобільність для здобуття освіти. Гнучкість полягає в можливості викладання матеріалу курсу з урахуванням підготовки та здібностей студентів. Актуальність виявляється в можливості запровадження новітніх педагогічних розробок із розбиттям матеріалу на окремі модулі або теми, які вивчаються в міру засвоєння i відповідають здібностям окремого студента або групи загалом. 


\section{V Висновки}

Дистанційне навчання $є$ унікальною системою підготовки і безперервної підтримки високого рівня кваліфрікації фахівців. Викладача вже не можна вважати носієм високої педагогічної майстерності, якщо він не володіє засобами, методами і технологіями дистанційного навчання. Діяльність викладача 3 використанням дистанційного навчання зазнає значних змін. Основним завданням викладача стає підготовка дистанційного навчального курсу на основі вже наявних оригінальних джерел та розробок, які входять до певних тематичних розділів. Стрімке поширення дистанційного навчання вплинуло на збільшення кількості навчальних програм і систем, а також освітніх середовищ та платформ дистанційного навчання. Найкращі з них мають стати щоденним робочим інструментом викладача.

Водночас дистанційна освіта в Україні все ще перебуває на початковому рівні, здебільшого через критику її як освіти нижчої якості. Кількість доступних програм та університетів, що пропонують дистанційне навчання, все ще обмежена. Відповідні технології впроваджують переважно для поліпшення традиційного навчання. Серед перешкод також $€$ відсутність або недосконалість національних стандартів, політик, процедур акредитації та регулювання; недостатня обізнаність на суспільному рівні, недостатня зацікавленість основних полісі-мейкерів у галузі вищої освіти, доволі слабка технологічна інфраструктура, відсутність гнучких можливостей фінансування. Утім, $є$ низка успішних ініціатив за останнє десятиліття, зокрема в НаУКМА.

\section{Бібліографічні посилання}

1. Антонов В. М. Дистанційне навчання: логіка, технології, перспективи : [кіберакмеологічний підхід]. Київ; Херсон : Штрих, 2011. 160 C.

2. Блощинський І. Г. Сутність та зміст поняття «дистанційне навчання» в зарубіжній та вітчизняній науковій літературі. Вісник Національної академії Державної прикордонної служби України. 2015. Вип. 3. URL: http://nbuv.gov.ua/UJRN/Vnadps_2015_3_4 (дата звернення: 10.06.2019).

3. Бублик В. В. Шляхами дистанційної освіти та електронного навчання. Наукові записки НаУКМА. Комп'ютерні науки. 2018. T. 1. C. 4-9. https://doi.org/10.18523/2617-3808.2018.4-9

4. Галецький С., Галецька Т. Дистанційне навчання як елемент інформаційно-комунікаційних технологій в освіті. Збірник наукових праць Уманського державного педагогічного університету імені Павла Тичини. 2018. Вип. 1. С. 54-62. URL: http://nbuv.gov.ua/UJRN/znpudpu_2018_1_8 (дата звернення: 10.06.2019).

5. Громова T. Митио Каку: Учеба уже не будет базироваться на запоминании. URL: http://www.dsnews.ua/society/mitiokaku-ucheba-uzhe-ne-budet-bazirovatsya-na-zapominanii-28082014231600 (дата звернення: 10.06.2019).

6. Журавська Н. С. Дистанційне навчання в країнах Європейського Союзу та Україні: реалії та перспективи. Науковий вісник Національного університету біоресурсів і природокористування України. Серія: Педагогіка, психологія, філософія. 2016. Вип. 233. С.101-106. URL: http://nbuv.gov.ua/UJRN/nvnau_ped_2016_233_17 (дата звернення: 10.06.2019).

7. Заболоцький А. Ю., Кочева Н. С. Дистанційне навчання у вищій школі для людей з особливими потребами. Молодий вчений. 2016. № 12. C. 429-432. URL: http://nbuv.gov.ua/UJRN/molv_2016_12_106 (дата звернення: 10.06.2019).

8. Кадемія М. Ю., Уманець В. О. Дистанційне навчання у віртуальному університеті як спосіб доступу до якісної освіти. Відкрите освітне е-середовище сучасного університету. 2016. Вип. 2. С. 175-184. URL: http://nbuv.gov.ua/UJRN/oeeemu_2016_2_15 (дата звернення: 10.06.2019).

9. Ключко С. С., Євтушенко В. М., Сирцов В. К. Сучасний освітній процес: курс на дистанційне навчання. Morphologia. 2017. T. 11, № 2. C. 58-60. URL: http://nbuv.gov.ua/UJRN/Morphology_2017_11_2_12 (дата звернення: 10.06.2019).

10. Козубовська І. В., Сагарда В. В., Пічкар О. П. Дистанційне навчання в системі освіти : навч. посіб. 2-ге вид., перероб., доповн. Ужгород : [б. в.], 2002. 361 c.

11. Концепція розвитку дистанційної освіти в Україні від 20.12.2000 p. URL: http://www.osvita.org.ua/distance/pravo/00.html (дата звернення: 10.06.2019).

12. Кухаренко В. М., Рибалко О. В., Сиротенко Н. Г. Дистанційне навчання: умови застосування : дистанційний курс : навч. посіб. Харків : Торсінг, 2002. 319 с.

13. Ляхоцька Л. Дистанційне навчання як педагогічна технологія неперервної освіти. Педагогічні науки. 2014. Вип. 61-62. C. 33-39. URL: http://dspace.pnpu.edu.ua/bitstream/123456789/3504/1/Liakhotska.pdf (дата звернення: 10.06.2019).

14. Муращенко Т. В. Змішане та дистанційне навчання як спосіб доступу до якісної освіти. Відкрите освітнє е-середовище сучасного університету. 2017. Вип. 3. URL: http://nbuv.gov.ua/UJRN/oeeemu_2017_3_45 (дата звернення: 10.06.2019).

15. Овсяннікова В. В. Дистанційне навчання в освітньому процесі вищого навчального закладу. Вісник Запорізького національного університету. Педагогічні науки. 2016. № 2. C. 56-60. URL: http://nbuv.gov.ua/UJRN/Vznu_ped_2016_2_10 (дата звернення: 10.06.2019).

16. Опанасюк Ю. Дистанційне навчання як наслідок еволюції традиційної системи освіти. Вища освіта України. 2016. № 1. C. 49-53. 
17. Організація дистанційного навчання. Створення електронних навчальних курсів та електронних тестів : навч. посіб. / Вишнівський В.В., Гніденко М. П., Гайдур Г. І., Ільїн О. О. Київ : ДУТ, 2014. 140 с.

18. Половая Н. О. Дистанційне навчання як інноваційна форма освіти. Грані. 2017. Т. 20, № 1. С. $27-31$. URL: http://nbuv.gov.ua/UJRN/Grani_2017_20_1_6 (дата звернення: 10.06.2019).

19. Про затвердження Положення про дистанційне навчання : наказ Міністерства освіти і науки України від 25 квітня 2013 р. № 466. URL: https://zakon.rada.gov.ua/laws/show/z0703-13 (дата звернення: 10.06.2019).

20. Про затвердження Програми розвитку системи дистанційного навчання на 2004-2006 роки : Постанова Кабінету Міністрів України від 23 вересня 2003 р. № 1494. URL: https://zakon.rada.gov.ua/laws/show/1494-2003-\%D0\%BF (дата звернення: 10.06.2019).

21. Про Національну програму інформатизації : Закон України станом на 10 липня 2002 р. : офріц. вид. / відп. ред. О. Д. Бурсук. Київ : Парламентське вид-во, 2002. 18 с. Додаток до нормативного бюлетеня «Відомості Верховної Ради України». URL: https://zakon.rada.gov.ua/laws/show/74/98-\%D0\%B2\%D1\%80 (дата звернення: 10.06.2019).

22. Про стан і перспективи розвитку дистанційного навчання в Україні : Рішення Колегії МОН України, Протокол № 6/2-4 від 23 червня 2005 p. URL: http://www.osvita.org.ua/distance/pravo/04.html (дата звернення: 10.06.2019).

23. Програмні засоби створення і супроводу розподіленого навчального середовища / І.В. Сергієнко, М. М. Глибовець, С. С. Гороховський, А. М. Глибовець; Нац. ун-т «Києво-Могилянська акад.». Київ : [НаУКМА], 2012. 709, [1] с.

24. Ставицька І. В. Моделі дистанційного навчання. Новітні освітні технології : зб. тез Х міжнар. наук.-практ. конфф., 14 січня 2015. URL: http://confesp.fl.kpi.ua/ru/node/1151 (дата звернення: 10.06.2019).

25. Altunoglu A. Initial perceptions of open higher education students with learner management systems. Turkish Online Journal of Distance Education (TOJDE). 2017. № 18 (3). P. 96-104. doi: https://doi.org/10.17718/tojde.328939

26. Barak M. Science teacher education in the twenty-first century: A pedagogical framework for technology-integrated social constructivism. Research in Science Education. 2017. № 47 (2). P. 283-303. doi:https://dx.doi.org/10.1007/s11165-015-9501y

27. Brecko B. N., Kampylis P., Punie Y. Mainstreaming ICT-enabled Innovation in Education and Training in Europe: Policy actions for sustainability, scalability and impact at system level; Joint Research Centre. Luxembourg: EUR-OP, 2014.1 online resource (56 p.). (EUR, 26601). (JRC scientific and policy reports). URL: http://ipts.jrc.ec.europa.eu/publications/pub.cfm?id=6361 (Last accessed: 10.06.2019). doi:10.2788/52088

28. Futures for Higher Education and ICT: Changes Due to the Use of Open Content / ed. by Svetlana Knyazeva ; UNESCO Institute for Information Technologies in Education. Moscow: UNESCO, 2016. URL: https://iite.unesco.org/pics/publications/en/files/3214745.pdf (Last accessed: 10.06.2019).

29. LMS Market by Component (Solution and Services), Delivery Mode (Distance Learning, Instructor-Led Training and Blended Learning), Deployment Type, User Type (Academic and Corporate), and Region - Global Forecast to 2023. Markets and markets. January 19. URL: https://www.marketsandmarkets.com/Market-Reports/learning-management-systems-market1266.html (Last accessed: 10.06.2019).

30. Miller G. History of Distance Learning. Worldwidelearn. Electronic data. 2014. URL: https://www.worldwidelearn.com/education-articles/history-of-distance-learning.html (Last accessed: 10.06.2019).

31. Picciano A. G. Online education policy and practice: the past, present, and future of the digital. New York : Routledge, [2017]. $x v i, 223 p$.

32. Picciano A. G. Online education: foundations, planning, and pedagogy. New York : Routledge, 2019. xvi, 193 p.

33. Rouse M. Massive open online course (MOOC). Whatis.techtarget. Electronic data. 2013. URL: https://whatis.techtarget.com/definition/massively-open-online-course-MOOC (Last accessed: 10.06.2019).

34. Shah D. 190 universities just launched 600 free online courses. Here's the full list. Quartz. Electronic data. 2018. October 25. URL: https://qz.com/1437623/600-free-online-courses-you-can-take-from-universities-worldwide/ (Last accessed: 10.06.2019).

35. The 2019 OpenupEd trend report on MOOCs / eds. George Ubachs, Lizzie Konings, Beau Nijsten. Maastricht: European Association of Distance Teaching Universities, 2019. 1 online resource (36 p.). URL: https://openuped.eu/images/Publications/The_2019_OpenupEd_Trend_Report_on_MOOCs.pdf (Last accessed: 10.06.2019).

\section{References}

1. Antonov, V. M. (2011). Dystantsiine navchannia: lohika, tekhnolohii, perspektyvy : [kiberakmeolohichnyi pidkhid]. Kyiv; Kherson: Shtrykh [in Ukrainian].

2. Bloshchynskyi, I. H. (2015). Sutnist ta zmist poniattia "dystantsiine navchannia" v zarubizhnii ta vitchyznianii naukovii literaturi. Visnyk Natsionalnoi akademii Derzhavnoi prykordonnoi sluzhby Ukrainy, 3. Retrieved from http://nbuv.gov.ua/UJRN/Vnadps_2015_3_4 [in Ukrainian].

3. Boublik, V. (2018). On road to distance education and e-learning. NaUKMA Research Papers. Computer Science, 1, 4-9. https://doi.org/10.18523/2617-3808.2018.4-9 [in Ukrainian].

4. Haletskyi S., Haletska T. (2018). Dystantsiine navchannia yak element informatsiino-komunikatsiinykh tekhnolohii v osviti. Zbirnyk naukovykh prats Umanskoho derzhavnoho pedahohichnoho universytetu imeni Pavla Tychyny, 1, 54-62. Retrieved from http://nbuv.gov.ua/UJRN/znpudpu_2018_1_8[in Ukrainian].

5. Gromova, T. (2014). Mitio Kaku: Ucheba uzhe ne budet bazirovat'sya na zapominanii. Retrieved from http://www.dsnews.ua/society/mitio-kaku-ucheba-uzhe-ne-budet-bazirovatsya-na-zapominanii-28082014231600 [in Russian]. 
6. Zhuravska, N. S. (2016). Dystantsiine navchannia v krainakh Yevropeiskoho Soiuzu ta Ukraini: realii ta perspektyvy [E-learning in the European Union and Ukraine: Realities and prospects]. Naukovyi visnyk Natsionalnoho universytetu bioresursiv $i$ pryrodokorystuvannia Ukrainy. Seriia: Pedahohika, psykholohiia, filosofiia, 233, 101-106. Retrieved from http://nbuv.gov.ua/UJRN/nvnau_ped_2016_233_17 [in Ukrainian].

7. Zabolotskyi, A. Yu., Kocheva, N. S. (2016). Dystantsiine navchannia u vyshchii shkoli dlia liudei z osoblyvymy potrebamy. Molodyi vchenyi, 12, 429-432. Retrieved from http://nbuv.gov.ua/UJRN/molv_2016_12_106 [in Ukrainian].

8. Kademiia, M. Yu., Umanets, V. O. (2016). Dystantsiine navchannia u virtualnomu universyteti yak sposib dostupu do yakisnoi osvity. Vidkryte osvitnie e-seredovyshche suchasnoho universytetu, 2, 175-184. Retrieved from http://nbuv.gov.ua/UJRN/oeeemu_2016_2_15[in Ukrainian].

9. Kliuchko, S. S., Yevtushenko, V. M., Syrtsov, V. K. (2017). Suchasnyi osvitnii protses: kurs na dystantsiine navchannia. Morphologia, 11(2), 58-60. Retrieved from http://nbuv.gov.ua/UJRN/Morphology_2017_11_2_12 [in Ukrainian].

10. Kozubovska, I. V., Saharda, V. V., Pichkar, O. P. (2002). Dystantsiine navchannia v systemi osvity. Uzhhorod [in Ukrainian].

11. Kontseptsiia rozvytku dystantsiinoi osvity v Ukraini (2000). Retrieved from http://www.osvita.org.ua/distance/pravo/00.html [in Ukrainian].

12. Kukharenko, V. M., Rybalko, O. V., Syrotenko, N. H. (2002). Dystantsiine navchannia: umovy zastosuvannia : dystantsiinyi kurs. Kharkiv: Torsinh [in Ukrainian].

13. Liakhotska, L. (2014). Dystantsiine navchannia yak pedahohichna tekhnolohiia neperervnoi osvity [Distance learning as pedagogical technology of continuing education]. Pedahohichni nauky, 61-62, 33-39. Retrieved from http://dspace.pnpu.edu.ua/bitstream/123456789/3504/1/Liakhotska.pdf [in Ukrainian].

14. Murashchenko, T. V. (2017). Zmishane ta dystantsiine navchannia yak sposib dostupu do yakisnoi osvity [Blended and distance learning as a way of access to quality education]. Vidkryte osvitnie e-seredovyshche suchasnoho universytetu, 3. Retrieved from http://nbuv.gov.ua/UJRN/oeeemu_2017_3_45 [in Ukrainian].

15. Ovsannikova, V. V. (2016). Dystantsiine navchannia v osvitnomu protsesi vyshchoho navchalnoho zakladu [Distance learning at the educational process of higher educational institution]. Visnyk Zaporizkoho natsionalnoho universytetu. Pedahohichni nauky, 2, 56-60. Retrieved from http://nbuv.gov.ua/UJRN/Vznu_ped_2016_2_10 [in Ukrainian].

16. Opanasiuk, Yu. (2016). Dystantsiine navchannia yak naslidok evoliutsii tradytsiinoi systemy osvity. Vyshcha osvita Ukrainy, 1 , 49-53 [in Ukrainian].

17. Vyshnivskyi, V. V., Hnidenko, M. P., Haidur, H. I., Ilin, O. O. (2014). Orhanizatsiia dystantsiinoho navchannia. Stvorennia elektronnykh navchalnykh kursiv ta elektronnykh testiv. Kyiv: DUT [in Ukrainian].

18. Polovaya, N. O. (2017). Dystantsiine navchannia yak innovatsiina forma osvity [Distance learning as an innovative form of education]. Grani, 20 (1), 27-31. Retrieved from http://nbuv.gov.ua/UJRN/Grani_2017_20_1_6. doi: 10.15421/17174 [in Ukrainian].

19. Pro zatverdzhennia Polozhennia pro dystantsiine navchannia : nakaz Ministerstva osvity i nauky Ukrainy (2013). Retrieved from https://zakon.rada.gov.ua/laws/show/z0703-13 [in Ukrainian].

20. Pro zatverdzhennia Prohramy rozvytku systemy dystantsiinoho navchannia na 2004-2006 roky : Postanova Kabinetu Ministriv Ukrainy № 1494 (2003). Retrieved from https://zakon.rada.gov.ua/laws/show/1494-2003-\%D0\%BF [in Ukrainian].

21. Pro Natsionalnu prohramu informatyzatsii : Zakon Ukrainy (2002). Retrieved from https://zakon.rada.gov.ua/laws/show/74/98$\%$ D0\%B2\%D1\%80 [in Ukrainian].

22. Pro stan i perspektyvy rozvytku dystantsiinoho navchannia v Ukraini : Rishennia Kolehii MON Ukrainy, Protokol № 6/2-4 (2005). Retrieved from http://www.osvita.org.ua/distance/pravo/04.html [in Ukrainian].

23. Serhiienko, I. V., Hlybovets, M. M. Horokhovskyi, S. S., Hlybovets, A. M. (2012). Prohramni zasoby stvorennia $i$ suprovodu rozpodilenoho navchalnoho seredovyshcha [The software for creation and maintenance of the distributed learning environment]. Kyiv: [The National University of Kyiv-Mohyla Academy] [in Ukrainian].

24. Stavytska, I. (2015). Modeli dystantsiinoho navchannia [Models of distance learning]. Novitni osvitni tekhnolohii. Retrieved from http://confesp.fl.kpi.ua/ru/node/1151 [in Ukrainian].

25. Altunoglu, A. (2017). Initial perceptions of open higher education students with learner management systems. Turkish Online Journal of Distance Education (TOJDE), 18 (3), 96-104. doi: https://doi.org/10.17718/tojde.328939

26. Barak, M. (2017). Science teacher education in the twenty-first century: A pedagogical framework for technology-integrated social constructivism. Research in Science Education, 47 (2), 283-303. doi:10.1007/s11165-015-9501-y

27. Brecko, B. N., Kampylis, P., Punie, Y. (2014). Mainstreaming ICT-enabled Innovation in Education and Training in Europe: Policy actions for sustainability, scalability and impact at system level. Joint Research Centre. Luxembourg: EUR-OP. 1 online resource (56 p.). (EUR, 26601). (JRC scientific and policy reports). Retrieved from http://ipts.jrc.ec.europa.eu/publications/pub.cfm?id=6361. doi:10.2788/52088

28. Knyazeva, S. (Ed.). (2016). Futures for Higher Education and ICT: Changes Due to the Use of Open Content. Moscow: UNESCO Institute for Information Technologies in Education. Retrieved from https://iite.unesco.org/pics/publications/en/files/3214745.pdf.

29. LMS Market by Component (Solution and Services), Delivery Mode (Distance Learning, Instructor-Led Training and Blended Learning), Deployment Type, User Type (Academic and Corporate), and Region - Global Forecast to 2023. (2019). Markets and markets. January 19. Retrieved from https://www.marketsandmarkets.com/Market-Reports/learning-managementsystems-market-1266.html.

30. Miller, G. (2014). History of Distance Learning. Worldwidelearn. Retrieved from https://www.worldwidelearn.com/educationarticles/history-of-distance-learning.html. 
31. Picciano A. G. [2017]. Online education policy and practice: the past, present, and future of the digital university. New York: Routledge.

32. Picciano, A. G. (2019). Online education: foundations, planning, and pedagogy. New York: Routledge.

33. Rouse, M. (2013). Massive open online course (MOOC). Whatis.techtarget. Retrieved from https://whatis.techtarget.com/definition/massively-open-online-course-MOOC.

34. Shah, D. (2018). 190 universities just launched 600 free online courses. Here's the full list. Quartz. October 25. Retrieved from https://qz.com/1437623/600-free-online-courses-you-can-take-from-universities-worldwide/.

35. Ubachs, G., Konings, L., Nijsten, B. (Eds.). (2019). The 2019 OpenupEd trend report on MOOCs. Maastricht: European Association of Distance Teaching Universities. Retrieved from https://openuped.eu/images/Publications/The_2019_OpenupEd_Trend_Report_on_MOOCs.pdf

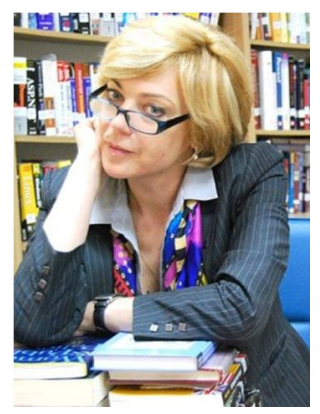

\section{Ярошенко Тетяна Олександрівна.}

К.і.н., доцент, віце-президент з науки та інформатизації,

Національний університет «Києво-Могилянська академія»,

вул. Г. Сковороди, 2, м. Київ, Україна, 04070.

Тел. 044 425-60-55. E-mail: yaroshenko@ukma.edu.ua

\section{Yaroshenko Tetiana Oleksandrivna.}

Ph.D. (history), Associate Professor, Vice-President for research and IT,

The National University of Kyiv-Mohyla Academy.

Vul. Skovorody, 2, Kyiv, Ukraine, 04070.

Tel. 044 425-60-55. E-mail: yaroshenko@ukma.edu.ua

ORCID: http://orcid.org/0000-0002-2985-2333

Researcher ID: F-8760-2016

\section{Citation (APA):}

Yaroshenko, T. (2019). Distance learning in higher education: current trends. Engineering and Educational Technologies, 7 (4), 8-21. doi: https://doi.org/10.30929/2307-9770.2019.07.04.01

\section{Цитування (ДСТУ 8302:2015):}

Ярошенко Т. О. Дистанційне навчання в системі вищої освіти: сучасні тенденції / ннженерні та освітні технології. 2019. Т. 7. № 4. C. 8-21. doi: https://doi.org/10.30929/2307-9770.2019.07.04.01

Обсяг cтатmi: $\quad$ сторінок-14 ; умовних друк. аркушів - 2,028. 